\title{
Adaptasi Riparian di Sekitar Sungai Tabobo Dusun Beringin Halmahera Utara: Tinjauan Fitoremediasi Pada Sungai Terindikasi Cemar
}

\author{
MUHLIS MUKARAM ${ }^{1}$, ZULKIFLI AHMAD $^{2}$, RETNO PENI SANCAYANINGSIH $^{3}$ \\ ${ }^{1}$ Guru SMA N 2 Kota Ternate \\ Jalan Inpres Ubo-Ubo Kota Ternate 97717 \\ email: muhlis_mukaram@yahoo.com \\ ${ }^{2}$ Program Studi Pendidikan Biologi, FKIP Universitas Khairun Ternate \\ J1. Bandara Baabullah kampus 1 Unkhair Akehuda Kota Ternate Utara 92714 \\ email: zulkifliahmad@unkhair.ac.id \\ ${ }^{3}$ Laboratorium Ekologi dan Konservasi Fakultas Biologi, UGM \\ Jl. Teknika Selatan, Sekip Utara, Sleman, Yogyakarta 55281 \\ email: retpeni@ugm.ac.id
}

\begin{abstract}
The Illegally Gold Mining Activities (PETI), which exacerbated to the water conditions of the Tabobo river. One of the higher problems for the people around PETI area was the use heavy metal mercury $(\mathrm{Hg})$. The purpose of this study was to determine the abundance of the plants that adaptable to the environtmental condition and to analyze concentration of mercury $(\mathrm{Hg})$ absorbed by riparian vegetation of Tabobo and Kao river, Malifut and Kao regencies, North Halmahera. Three rivers were selected, two of them represented the high intensity of gold mining, Tabobo and Kao rivers, and Umbul Nilo water spring output at Margosuko, Daleman village, Klaten subregency as a control area. In each station were placed six square plots $\left(1 \times 1 \mathrm{~m}^{2}\right.$ size $)$ located in the upstream, midstream, and the down-stream of the selected river sites. The mercury content absorbed by dominant plants samples was analyzed using Mercury Analyzer after wet destruction. The research results showed that Poaceaae, Commelinaceae, and Convolvulaceae were found both in Tabobo and Nilo river, especially Digitaria and Commelina genera, while Panicum and Paspalum were only found in 2 polluted rivers, Tabobo and Kao. These assumed that they function as plant accumulator. The mercury content in the leaves of Paspalum sp. both in upstream and midstream of Tabobo river, has lower value compared to the standard $(<0.01 \mathrm{ppb})$, but in the downstream showed that mercury level absorbed by Paspalum sp. leaves was high (11.57 ppb). Mercury levels of Macaranga sp. leaves tree in Beringin village had the value of the $36.45 \mathrm{ppb}$. On the contrary, mercury analysis of Panicum repens L. leaves representing floor vegetation, and leaves of Macaranga semiglobosa J.J.S. surrounding Kao river showed that the mercury contents were below the threshold value $(<0.01 \mathrm{ppb})$.
\end{abstract}

Keywords: adaptation, fitoremediation, Halmahera Utara, Riparian, Tabobo

\section{PENDAHULUAN}

Dusun Beringin merupakan suatu pemukiman yang berada dekat dengan Sungai Tabobo. Daerah ini mulai berkembang pesat sejak dibukanya pertambangan emas pada Tahun 1997. Kedatangan warga dalam jumlah yang sangat besar tersebut memiliki tujuan utama mencari dan mendapatkan emas. Teknik pengolahan emas yang dilakukan oleh masyarakat masih menggunakan teknik sederhana dengan cara amalgamasi. Hampir di setiap tepi sungai sepanjang sungai Tabobo terdapat tromol dengan gelondong yang masih aktif untuk mengolah bijih emas. Sehingga dalam kurun waktu 10 tahun sejak dibukanya daerah pertambangan, mulai nampak tandatanda tercemarnya sungai dengan beberapa indikator, mulai dari keruhnya air sungai, hilangnya beberapa jenis ikan dan organisme perairan lain, serta keresahan masyarakat yang ada di sekitar sungai tersebut.

Masalah pencemaran perairan sejak dua dekade ini sangat memprihatinkan, karena limbah yang terdapat dalam perairan sudah 
melebihi batas yang dapat ditoleransi oleh biota perairan (Jenkins, 1978 dalam Moro 2011). Pencemaran perairan menyebabkan terganggunya keseimbangan ekosistem, pendayagunaan air menjadi terbatas dan berdampak serius terhadap kesehatan masyarakat.

Penyebab pencemaran perairan antara lain karena penggunaan bahan bakar fosil, limbah industri, buangan limbah domestik, pemakaian pestisida dan pertambangan. Logam berat dalam perairan dapat teradsorpsi dan terakumulasi dalam tubuh organisme air, selanjutnya terlibat dalam rantai makanan sehingga menyebabkan bioakumulasi. Untuk mengetahui besarnya tingkat pencemaran suatu perairan oleh logam berat, telah banyak dikembangkan pemantauan secara kimia, dengan menentukan kadar setiap zat pencemar pada air ataupun sedimen.

Berdasarkan hasil observasi awal dan wawancara dengan masyarakat sekitar perairan Sungai Tabobo dusun Beringin, menyebutkan bahwa hampir kurang lebih 5 tahun terakhir sebagian besar masyarakat sudah tidak lagi menggunakan dan mengambil air dari sungai Tabobo. Hasil analisis merkuri oleh Zam zam (2008) di air sungai Kobok dan Tabobo Kecamatan Malifut, menunjukkan bahwa di kedua sungai tersebut diduga telah mengandung unsur merkuri dengan konsentrasi 0,075 ppm dan 0,000049 ppm. Konsentrasi logam merkuri yang terkontaminasi di air sungai Tabobo belum melampaui baku mutu yang ditetapkan. Meskipun demikian, potensi pencemaran air sungai tetap tinggi dan kewaspadaan terhadap akumulasi merkuri pada sedimen sungai perlu diperhatikan (Zam zam, 2008). Berdasarkan beberapa fakta inilah, sehingga membuat sebagian besar masyarakat tidak lagi menggunakan air sungai dan sumur yang ada di sekitar perairan sungai Tabobo.

Selain itu, maraknya kegiatan Pertambangan Emas Tanpa Izin (PETI) oleh masyarakat sekitar perairan sungai, juga semakin memperparah kondisi perairan Sungai Tabobo. Berdasarkan hasil observasi awal, di beberapa titik sepanjang alur sungai Tabobo dusun Beringin, ditemukan \pm 50 gelondong yang masih aktif beroperasi. Secara resmi aktivitas pertambangan emas yang dikelola oleh masyarakat ini tidak diizinkan oleh pemerintah, baik tingkat propinsi maupun tingkat kabupaten.

Kegiatan PETI tersebut secara langsung dapat mempengaruhi komunitas tumbuhan riparian dengan berbagai stratifikasi, mulai tingkat pohon, pancang, herba, semak dan rumput melalui luapan tailing dan secara tidak langsung melalui penyerapan akar. Beberapa jenis tumbuhan riparian dapat dimanfaatkan juga sebagai makanan dan pakan ternak. Apabila logam berat (merkuri) telah masuk dalam rantai makanan, dikhawatirkan akan berdampak pada kesehatan manusia. Besarnya tingkat konsentrasi merkuri $(\mathrm{Hg})$ yang terserap dan terakumulasi oleh tumbuhan riparian yang ada di perairan Sungai Tabobo, sampai saat ini belum diungkap secara ilmiah, sehingga menjadi persoalan menarik yang sangat perlu untuk dikaji.

\section{METODE}

Pengambilan Sampel. Pengambilan cuplikan sampel tumbuhan dilakukan di tiga lokasi, yaitu di sungai Tabobo dengan intensitas penggelondongannya tinggi, di sungai Kao yang tidak ada aktifitas gelondongan, namun keduanya berada pada satu daratan Halmahera, dan sungai Klaten sebagai pembanding. Selanjutnya ketiga lokasi tersebut ditetapkan sebagai stasiun penelitian, dan masing-masing stasiun diletakkan sebanyak enam kuadrat di daerah hulu, tengah dan hilir, dengan ketentuan 3 kuadrat di letakkan di tepi kanan dan tiga lainnya di tepi kiri sungai.

Pengumpulan Data. Pengumpulan data dilakukan di area quarry sungai Tabobo. Data pada area quarry sangat dipengaruhi oleh beberapa faktor, diantaranya; jumlah gelondong, frekuensi penggunaan gelondong, banyaknya bahan baku (merkuri atau sianida) yang digunakan, dan lamanya penggunaan (pengoperasian) gelondong. Penentuan plot penelitian berdasarkan jumlah gelondong yang terbanyak memasukkan limbahnya ke badan air di sungai Tabobo. Pengumpulan 
data vegetasi meliputi kegiatan identifikasi dan pencuplikan tumbuhan, analisis vegetasi tingkat herba dan pancang, serta analisis tingkat pohon. Pada setiap plot penelitian, specimen tumbuhan herba, rumput, maupun cuplikan anggota organ pohon yang belum diketahui nama ilmiahnya, dibuat herbarium untuk kemudian diidentifikasi nama ilmiahnya. Kegiatan identifikasi jenis tumbuhan dilakukan dengan mengacu pada buku Flora karangan J.J.Van Steenis. Apabila jenis tumbuhan tersebut tidak dapat di identifikasi secara langsung di lapangan, maka dibuat awetan kering dalam bentuk herbarium, kemudian dibawa ke Laboratorium Taksonomi Tumbuhan Universitas Gadjah Mada untuk diidentifikasi. Peletakkan transek di setiap area quarry, dilakukan secara stratified random.

Pencuplikan tumbuhan menggunakan metode kuadrat untuk tumbuhan rumput dan semak, dan metode plotless (Point Centerred Quarter Methods-PCQM) untuk pohon. Penentuan area quary untuk pencuplikan didasarkan atas jumlah gelondong terbanyak, sehingga ditetapkan daerah pencuplikan di daerah hulu, tengah, dan hilir dengan masingmasing titik ditentukan 3 plot sebelah kiri dan kanan dari badan sungai. Jumlah plot di sungai Tabobo berjumlah 18 plot (hulu=6 plot, tengah $=6$ plot, dan hilir $=6$ plot), sementara pada sungai Kao dan Sungai Klaten dibuat sebanyak 6 plot sehingga secara keseluruhan total jumlah plot $=30$ plot. Metode kuadrat digunakan untuk tumbuhan bawah (ground) dengan ukuran plot $1 \mathrm{x} 1 \mathrm{~m}$.

Dalam metode PCQM digunakan jarak $15 \mathrm{~m}$ antar subtransek dan $10 \mathrm{~m}$ antar titik, dengan empat kuadran pada setiap titik. Pengulangan dilakukan pada tiga stasiun, dua stasiun sebagai pembanding dan dianggap tidak ada quarry, dan satu stasiun lainnya merupakan daerah sampling dengan quarry yang intensitas penggelondongannya tinggi. Pengambilan sampel tumbuhan dilakukan pada jenis-jenis tumbuhan riparian yang tumbuh dominan di area pembuangan limbah tailing dan area kegiatan PETI. Pada setiap kuadran, dicuplik satu tumbuhan baik tingkat pohon, anak pohon, maupun seedling yang mempunyai jarak terdekat dengan titik penempatan (O). Kemudian diukur jarak antara titik penempatan dengan tumbuhan yang dicuplik, diukur juga diameter batang pohon (DBH) untuk pohon yang dicuplik, yaitu setinggi dada $( \pm 135 \mathrm{~cm})$ atau di atas banir.Parameter lingkungan yang diukur dalam penelitian ini merupakan data pendukung yang diukur secara bersamaan pada waktu pengambilan cuplikan sampel tumbuhan riparian.

Pengukuran parameter lingkungan. Pengukuran parameter lingkungan meliputi parameter fisik seperti suhu, jumlah debit air dan kecepatan arus, serta paramater kimia seperti $\mathrm{pH}$. Setelah data vegetasi dikumpulkan, kemudian dihitung paramaterparameter vegetasinya; densitas, frekuensi, dominansi dan nilai penting. Analisis data dilakukan secara deskriptif kuantitatif. Data kandungan $\mathrm{Hg}$ dalam tumbuhan riparian di Sungai Tabobo, selanjutnya dibandingkan dengan data pembanding, antara lain; data kandungan $\mathrm{Hg}$ dalam tumbuhan di Sungai Kao, dan Keputusan Menteri Lingkungan Hidup No.02/MENKLH/I/1998.

\section{HASIL}

Hasil dari penelitian ini tergambar pada tabel dan gambar berikut:

Tabel 1. Rekapitulasi Komposisi jenis tumbuhan riparian yang ditemukan di sungai Tabobo, Kao dan Umbul Nila Klaten

\begin{tabular}{clllccc}
\hline No. Familia & Genus & Nama Jenis & $\begin{array}{c}\text { Sungai } \\
\text { Tabobo }\end{array}$ & $\begin{array}{c}\text { Sungai } \\
\text { Kao }\end{array}$ & $\begin{array}{c}\text { Sungai } \\
\text { Klaten }\end{array}$ \\
\hline 1. & Poaceae & Setaria & Setaria sp. & $\sqrt{ }$ & - & - \\
\cline { 3 - 6 } & Digitaria & $\begin{array}{l}\text { Digitaria adscendens } \\
\text { (H.B.K.) Henr. }\end{array}$ & $\sqrt{ }$ & - & $\sqrt{ }$ \\
\cline { 3 - 6 } & & Digitaria rhopaloides & $\sqrt{ }$ & - & $\sqrt{ }$ \\
\cline { 3 - 5 } & & $\begin{array}{l}\text { Digitaria diversinervis } \\
\text { (Nees) Stapt. }\end{array}$ & - & - & $\sqrt{ }$ \\
\hline
\end{tabular}




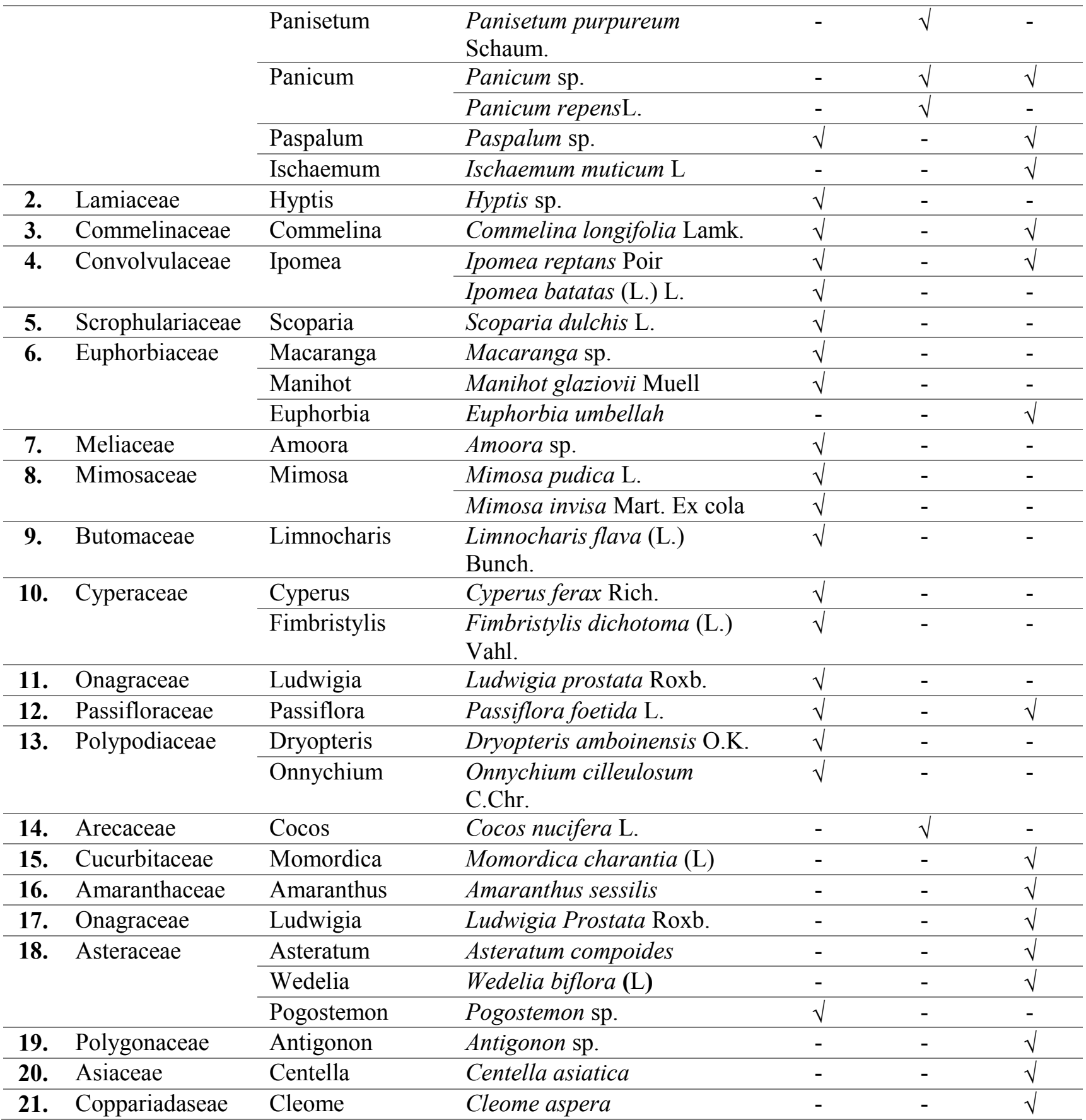

Tabel 2. Nilai parameter vegetasi lantai di sekitar sungai Tabobo

\begin{tabular}{llccccccc}
\multirow{2}{*}{ No. } & \multirow{2}{*}{ Nama Jenis } & \multicolumn{3}{c}{ Total Ind/Titik } & $\sum$ & Rerata & Frek Rel & Dens \\
\cline { 2 - 7 } & Hulu & Tengah & Hilir & & & & Rel \\
\hline 1. & Cyperus ferax Rich & 4 & 1 & 0 & 5 & 1,67 & 0,67 & $0 \%$ \\
\hline 2. & Digitaria adscendens (H.B.K.) Henr. & 34 & 6 & 0 & 40 & 13,33 & 0,67 & $3 \%$ \\
\hline 3. & Ipomea reptans Poir. & 0 & 0 & 9 & 9 & 3 & 0,33 & $1 \%$ \\
\hline 4. & Panicum sp. & 125 & 150 & 0 & 275 & 91,67 & 0,67 & $21 \%$ \\
\hline 5. & Pogostemon sp. & 4 & 0 & 0 & 4 & 1,33 & 0,33 & $0 \%$ \\
\hline 6. & Limnocharis flava (L.) Bunch. & 0 & 1 & 0 & 1 & 0,33 & 0,33 & $0 \%$ \\
\hline 7. & Fimbristylis dichotoma (L.) Vahl. & 0 & 8 & 0 & 8 & 2,67 & 0,33 & $1 \%$ \\
\hline 8. & Hyptis sp. & 0 & 1 & 0 & 1 & 0,33 & 0,33 & $0 \%$ \\
\hline 9. & Setaria sp. & 0 & 0 & 40 & 40 & 13,33 & 0,33 & $3 \%$ \\
\hline 10. & Commelina longifolia Lamk. & 0 & 0 & 22 & 22 & 7,33 & 0,33 & $2 \%$ \\
\hline
\end{tabular}




\begin{tabular}{llccccccc}
\hline 11. & Ludwigia prostata Roxb. & 0 & 0 & 1 & 1 & 0,33 & 0,33 & $0 \%$ \\
\hline 12. & Scoparia dulchis L. & 0 & 0 & 180 & 180 & 60 & 0,33 & $13 \%$ \\
\hline 13. & Mimosa pudica L. & 0 & 10 & 0 & 10 & 3,33 & 0,33 & $1 \%$ \\
\hline 14. & Mimosa invisa Mart Ex. Cola & 0 & 7 & 0 & 7 & 2,33 & 0,33 & $1 \%$ \\
\hline 15. & Paspalum sp. & 218 & 304 & 171 & 693 & 231 & 1 & $52 \%$ \\
\hline 16. & Dryopteris amboinensis O.K. & 0 & 26 & 0 & 26 & 8,67 & 0,33 & $2 \%$ \\
\hline 17. & Onnychium cilleusom C.Chr. & 0 & 1 & 0 & 1 & 0,33 & 0,33 & $0 \%$ \\
\hline 18. & Passiflora foetida L. & 1 & 0 & 0 & 1 & 0,33 & 0,33 & $0 \%$ \\
\hline 19. & Ipomea batatas (L) L. & 0 & 0 & 6 & 6 & 2 & 0,33 & $0 \%$ \\
\hline & TOTAL & & & & 1335 & & 8 & $100 \%$ \\
\hline
\end{tabular}

Tabel 3. Nilai parameter vegetasi tingkat pohon di sekitar sungai Tabobo

\begin{tabular}{|c|c|c|c|c|c|c|c|c|}
\hline \multirow[b]{2}{*}{ No. Nama Jenis } & \multirow{2}{*}{ Ind } & D & DR & $\mathbf{F}$ & FR & Dom & DmR & NP \\
\hline & & & $\%$ & & $\%$ & \multicolumn{3}{|c|}{$\%$} \\
\hline 1. Macaranga sp. & 6 & 1,07 & 50 & 100 & 33,33 & 794,53 & 54,21 & 137,55 \\
\hline 2. Amoora sp. & 3 & 0,54 & 25 & 100 & 33,33 & 347,53 & 23,71 & 82,05 \\
\hline 3. Macaranga rhizinoides (B.L.) M.A. & 2 & 0,36 & 16,67 & 66,67 & 22,22 & 235,92 & 16,1 & 54,99 \\
\hline 4. Manihot glaziovii Muell. & 1 & 0,18 & 8,33 & 33,33 & 11,11 & 87,56 & 5,97 & 25,42 \\
\hline TOTAL & 12 & 2,14 & 100 & 300 & 100 & 1465,54 & 100 & 300 \\
\hline
\end{tabular}

Tabel 4. Nilai parameter vegetasi lantai yang ditemukan di sungai Kao

$\begin{array}{lccccccc} & \text { Plot } & \text { Plot Kiri } & \text { Total } & \text { Rerata } & \begin{array}{l}\text { Frek } \\ \text { Rel }\end{array} & \begin{array}{l}\text { Dens } \\ \text { Rel }\end{array} & \text { Ket }\end{array}$

\begin{tabular}{lllllll}
\cline { 2 - 5 } & 1 & 2 & 3 & 1 & 2 & 3
\end{tabular}

\begin{tabular}{lllllllllllll} 
1. & Panicum repens L. & 7 & 9 & 0 & 7 & 0 & 0 & 23 & 3,83 & 0,5 & $47 \%$ & Dom \\
\hline 2. & Pannisetum purpureum & 0 & 0 & 0 & 0 & 4 & 12 & 16 & 2,67 & 0,33 & $33 \%$ &
\end{tabular} Schaum

\begin{tabular}{lllllllllll}
\hline 3. Ipomea reptans Poir. & 0 & 0 & 4 & 0 & 0 & 0 & 4 & 0,67 & 0,17 & $8 \%$
\end{tabular}

4. Paspalum sp. $\quad 000000012 \%$

$\begin{array}{llll}\text { Jumlah } & 26 & 0,67 & 100 \%\end{array}$

Tabel 5. Nilai parameter vegetasi tingkat pohon di sungai Kao

\begin{tabular}{|c|c|c|c|c|c|c|c|c|}
\hline \multirow{2}{*}{ No. Nama Jenis } & \multirow{2}{*}{$\sum$ Ind } & D & DR & $\mathbf{F}$ & FR & Dom & DmR & NP \\
\hline & & \multicolumn{3}{|c|}{$\%$} & $\%$ & \multicolumn{3}{|c|}{$\%$} \\
\hline 1. Macaranga semiglobosa J.J.S. & 3 & 1,39 & 33,33 & 100 & 37,5 & 1078,11 & 47,51 & 118,34 \\
\hline 2. Cocos nucifera & 5 & 0,69 & 16,67 & 66,67 & 25 & 148,49 & 6,54 & 48,21 \\
\hline 3. Macaranga rhizinoides (BI.) M.A. & 2 & 2,08 & 50 & 100 & 37,5 & 1042,69 & 45,95 & 133,45 \\
\hline TOTAL & 10 & 4,16 & 100 & 266,67 & 100 & 2269,29 & 100 & 300 \\
\hline
\end{tabular}

Tabel 6. Nilai parameter vegetasi lantai yang ditemukan di sungai Umbul NilaKlaten

\begin{tabular}{llccccccc}
\hline \multirow{2}{*}{ No. Nama Jenis } & \multicolumn{3}{c}{ Total Ind/Titik } & $\sum$ & Rerata & Frek & \multicolumn{2}{l}{$\begin{array}{l}\text { Dens } \\
\text { Rel }\end{array}$} \\
\cline { 2 - 9 } & Hulu & Tengah & Hilir & & & Rel \\
\hline 1. & Momordica charantia (L.) & 0 & 0 & 1 & 1 & 0,17 & 0,33 & 0,324 \\
\hline 2. & Panicum sp. & 17 & 7 & 4 & 28 & 4,67 & 0,83 & 9,061 \\
\hline 3. & Amaranthus sessilis & 11 & 0 & 0 & 11 & 1,83 & 0,33 & 3,560 \\
\hline 4. & Paspalum sp. & 3 & 25 & 0 & 28 & 4,67 & 0,33 & 9,061 \\
\hline 5. & Amaranthus sp. & 1 & 0 & 3 & 4 & 0,67 & 0,33 & 1,294 \\
\hline 6. & Ludwigia prostata Roxb. & 5 & 2 & 0 & 7 & 1,17 & 0,33 & 2,265 \\
\hline 7. & Angeratum compoides & 13 & 0 & 0 & 13 & 2,17 & 0,17 & 4,207 \\
\hline
\end{tabular}




\begin{tabular}{|c|c|c|c|c|c|c|c|}
\hline 8. Commelina Longifolia Lamk. & 41 & 16 & 11 & 68 & 11,33 & 0,83 & 22,006 \\
\hline 9. Digitaria rhopaloides & 3 & 0 & 0 & 3 & 0,50 & 0,17 & 0,971 \\
\hline 10. Antigonon sp. & 0 & 0 & 45 & 45 & 7,50 & 0,17 & 14,563 \\
\hline 11. Centella asiatica & 0 & 0 & 2 & 2 & 0,33 & 0,17 & 0,647 \\
\hline 12. Digitaria divensinervis (Nees) Stopf. & 4 & 0 & 28 & 32 & 5,33 & 0,50 & 10,356 \\
\hline 13. Digitaria $\mathrm{Sp}$ & 0 & 2 & 6 & 8 & 1,33 & 0,33 & 2,589 \\
\hline 14. Cleome aspera & 0 & 0 & 1 & 1 & 0,17 & 0,17 & 0,324 \\
\hline 15. Ischaemum muticum L. & 4 & 0 & 4 & 8 & 1,33 & 0,33 & 2,589 \\
\hline 16. Paspalum conjugatum & 0 & 0 & 30 & 30 & 5,00 & 0,33 & 9,709 \\
\hline 17. Ipomea reptans Poir. & 0 & 0 & 1 & 1 & 0,17 & 0,17 & 0,324 \\
\hline 18. Wedelia biflora $(\mathrm{L})$ & 0 & 0 & 5 & 5 & 0,83 & 0,17 & 1,618 \\
\hline 19. Euphorbia umbellah & 0 & 0 & 2 & 2 & 0,33 & 0,17 & 0,647 \\
\hline 20. Digitaria adscendens (H.B.K) Henr. & 0 & 0 & 5 & 5 & 0,83 & 0,17 & 1,618 \\
\hline 21. Possiflora foetida O.K. & 0 & 0 & 3 & 3 & 0,50 & 0,17 & 0,971 \\
\hline TOTAL & & & & 309 & 51,50 & 6,83 & 100,00 \\
\hline
\end{tabular}

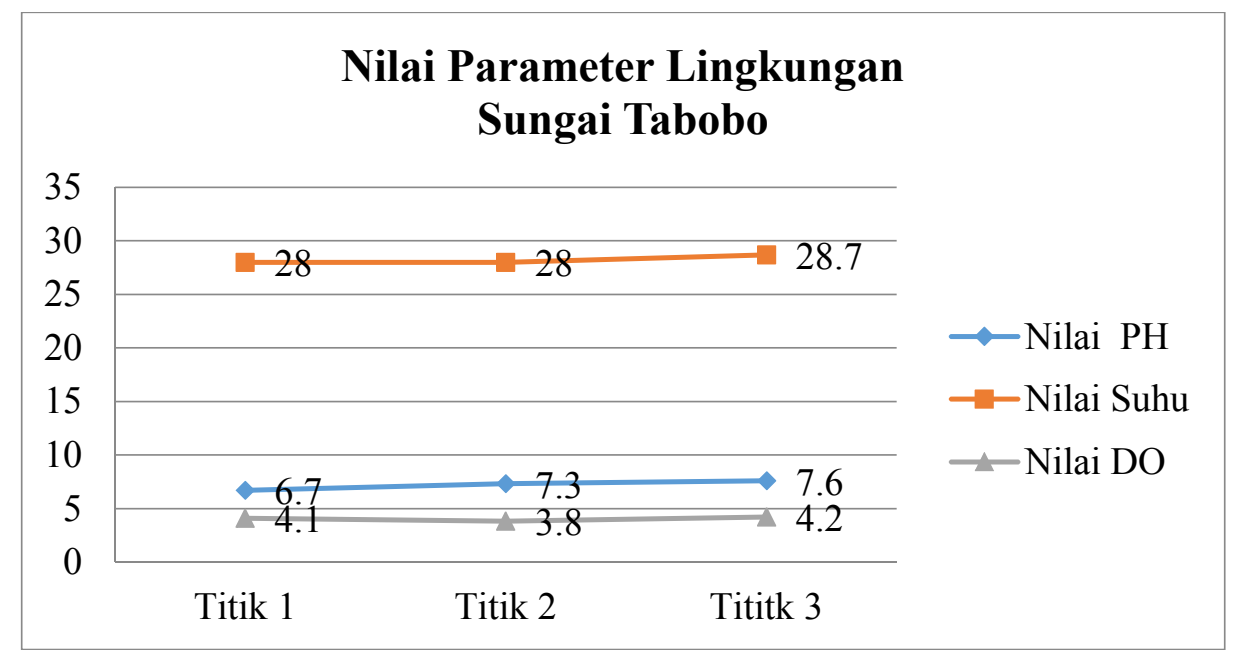

Gambar 1. Grafik nilai parameter lingkungan di Sungai Tabobo

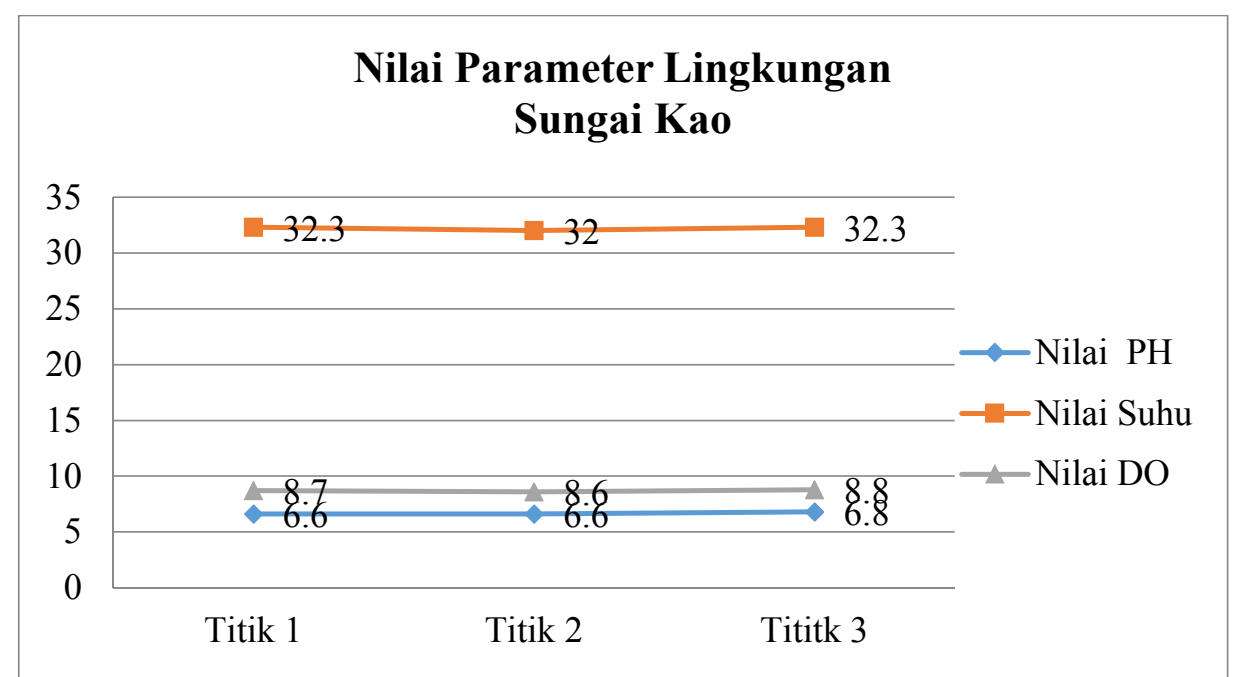

Gambar 2. Grafik nilai parameter lingkungan di Sungai Kao 
Tabel 7. Hasil analisis merkuri pada sampel tumbuhan

\begin{tabular}{|c|c|c|c|c|c|c|}
\hline Stasiun & Nama Jenis & $\begin{array}{c}\text { Bagian } \\
\text { tumbuhan (yang } \\
\text { dianalisis) }\end{array}$ & strata & $\begin{array}{l}\text { Nilai } \\
\text { merkuri } \\
\text { terukur } \\
(\mathrm{ppb})\end{array}$ & $\begin{array}{l}\text { Nilai } \\
\text { Ambang } \\
\text { Batas } \\
(\mathrm{ppb})\end{array}$ & Ket \\
\hline \multirow{8}{*}{ Tabobo } & Paspalum sp. & Daun & Lantai & $<0,01$ & 0,01 & DBA \\
\hline & Paspalum sp. & Daun & Lantai & $<0,01$ & 0,01 & DBA \\
\hline & Paspalum sp. & Daun & Lantai & $<0,01$ & 0,01 & DBA \\
\hline & Paspalum sp. & Daun & Lantai & $<0,01$ & 0,01 & DBA \\
\hline & Paspalum sp. & Daun & Lantai & $<0,01$ & 0,01 & DBA \\
\hline & Paspalum sp. & Daun & Lantai & 11,57 & 0,01 & DAA \\
\hline & Amoora sp. & Daun & Pohon & $<0,01$ & 0,01 & DBA \\
\hline & Macaranga sp. & Daun & Pohon & 36,45 & 0,01 & DAA \\
\hline \multirow[t]{2}{*}{ Kao } & Panicum repens L. & Daun & Lantai & $<0,01$ & 0,01 & DBA \\
\hline & Macaranga semiglobosa J.J.S. & Daun & Pohon & $<0,01$ & 0,01 & DBA \\
\hline $\begin{array}{l}\text { Ket: } \\
\text { DAA } \\
\text { DBA }\end{array}$ & $\begin{array}{l}\text { ambang batas dari nilai yang } \\
\text { wah ambang batas dari nilai ya }\end{array}$ & $\begin{array}{l}\text { apkan } \\
\text { litetapkan }\end{array}$ & & & & \\
\hline
\end{tabular}

Tabel 8. Hasil analisis kadar merkuri pada sampel tanah

\begin{tabular}{|c|c|c|c|c|c|}
\hline Stasiun & Titik & No.Plot & $\begin{array}{l}\text { Nilai merkuri } \\
\text { terukur (ppb) }\end{array}$ & $\begin{array}{l}\text { Nilai Ambang batas } \\
\text { (ppb) }\end{array}$ & Ket. \\
\hline \multirow[t]{18}{*}{ Tabobo } & \multirow[t]{6}{*}{ Hulu } & KA.1.1 & 2,45 & 0,12 & DAA \\
\hline & & KA.1.2 & 67,56 & 0,12 & DAA \\
\hline & & KA.1.3 & 56,07 & 0,12 & DAA \\
\hline & & KI.1.1 & 0,46 & 0,12 & DAA \\
\hline & & KI.1.2 & 0,52 & 0,12 & DAA \\
\hline & & KI.1.3 & $<0,12$ & 0,12 & DBA \\
\hline & \multirow[t]{6}{*}{ Tengah } & KA.2.1 & 8,96 & 0,12 & DAA \\
\hline & & KA.2.2 & 7,34 & 0,12 & DAA \\
\hline & & KA.2.3 & 14,21 & 0,12 & DAA \\
\hline & & KI.2.1 & 173,72 & 0,12 & DAA \\
\hline & & KI.2.2 & 31,52 & 0,12 & DAA \\
\hline & & KI.2.3 & 12,31 & 0,12 & DAA \\
\hline & \multirow[t]{6}{*}{ Hilir } & KA.3.1 & 108,84 & 0,12 & DAA \\
\hline & & KA.3.2 & 10,53 & 0,12 & DAA \\
\hline & & KA.3.3 & 2,24 & 0,12 & DAA \\
\hline & & KI.3.1 & 9,75 & 0,12 & DAA \\
\hline & & KI.3.2 & 10,60 & 0,12 & DAA \\
\hline & & KI.3.3 & 22,99 & 0,12 & DAA \\
\hline \multirow[t]{6}{*}{ Kao } & \multirow[t]{3}{*}{ Kanan sungai } & KAO.1.1 & $<0,12$ & 0,12 & DBA \\
\hline & & KAO.1.2 & 1,13 & 0,12 & DAA \\
\hline & & KAO.1.3 & 0,97 & 0,12 & DAA \\
\hline & \multirow[t]{3}{*}{ Kiri sungai } & KAI.1.1 & $<0,12$ & 0,12 & DBA \\
\hline & & KAI.1.2 & 23,52 & 0,12 & DAA \\
\hline & & KAI.1.3 & $<0,12$ & 0,12 & DBA \\
\hline
\end{tabular}

Ket:

DAA = diatas ambang batas dari nilai yang ditetapkan

DBA = di bawah ambang batas dari nilai yang ditetapkan 


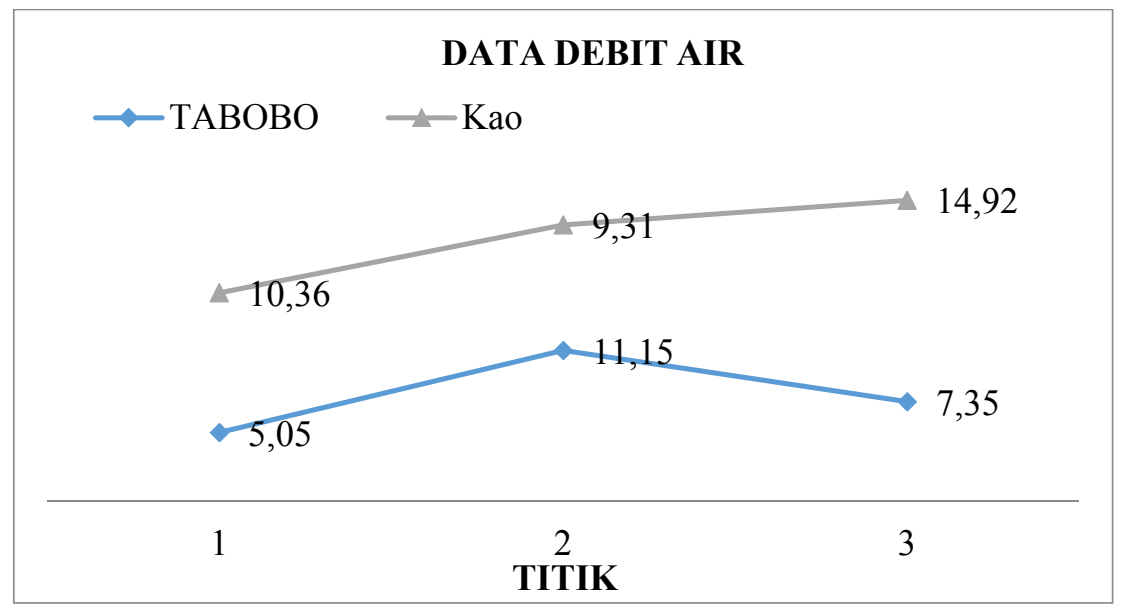

Gambar 3. Grafik nilai debit air di dua lokasi kajian

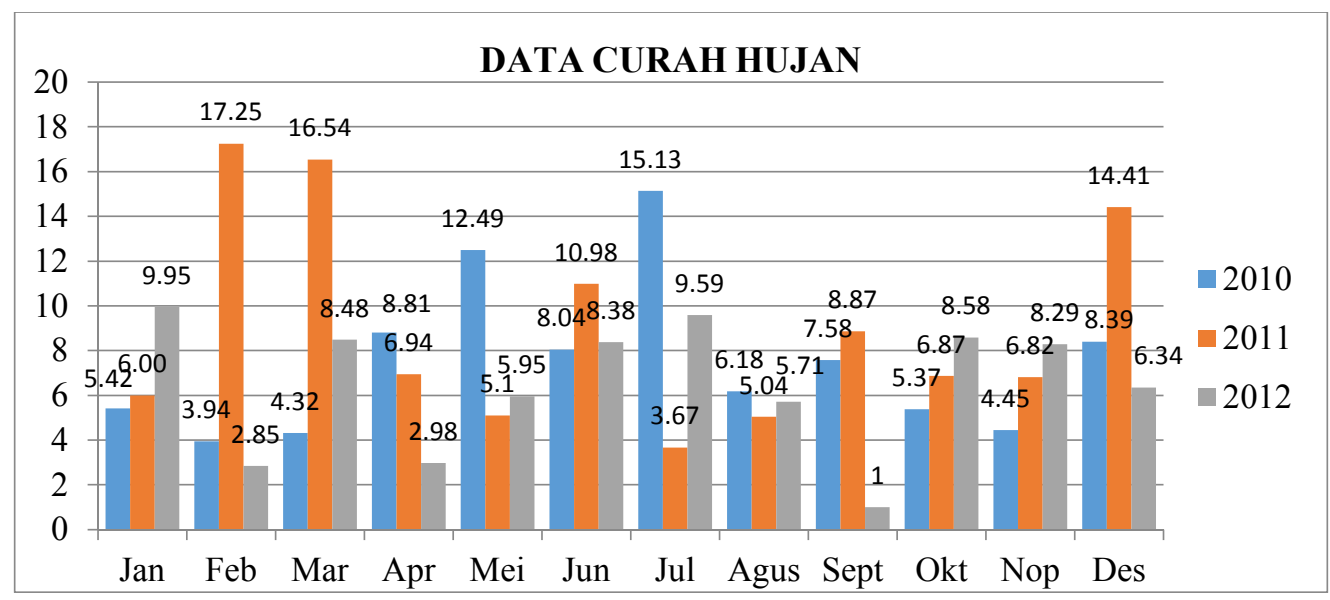

Gambar 4. Grafik data curah hujan pada dua tahun terakhir

\section{PEMBAHASAN}

Komposisi jenis Tumbuhan Riparian di Sungai Tabobo, Kao, dan Umbul Nila Klaten. Berdasarkan hasil identifikasi secara keseluruhan sampel jenis tumbuhan yang ditemukan pada plot bagian hulu, tengah dan hilir di tiga sungai kajian, ditemukan 36 jenis tumbuhan riparian, yang tergolong dalam 21 famili. Data tentang komposisi jenis tumbuhan riparian yang ditemukan di lokasi sampling sungai Tabobo, Kao dan Umbul Nila Klaten disajikan pada Tabel 1.

Vegetasi lantai di sekitar quarry penggelondongan emas sungai Tabobo memiliki kerapatan tertinggi adalah pada jenis Paspalum sp. (52\%), dan nilai penting tertinggi untuk tingkat pohon adalah jenis Macaranga sp.(INP=137,55\%) (Tabel 2 dan Tabel 3). Sedangkan vegetasi lantai di sekitar sungai Kao memiliki kerapatan tertinggi adalah pada jenis Panicum repens L. (47\%), dan nilai penting tertinggi untuk tingkat pohon adalah jenis Macaranga semiglobosa J.J.S. (INP=133,45\%) (Tabel 4 dan Tabel 5).

Vegetasi lantai di sekitar sungai Umbul Nila Klaten (Tabel 6) ditemukan 21 jenis tumbuhan yang tergolong dalam 19 famili dengan nilai kerapatan relatif tertinggi adalah jenis Commelina Longifolia Lamk (22\%). Kehadiran jenis Commelina Longifolia Lamk juga sering ditemukan di setiap cuplikan plot. Dari hulu sampai ke hilir sungai, tumbuhan jenis Commelina Longifolia Lamk mendominasi di sepanjang bantaran sungai.

Nilai parameter lingkungan yang terukur pada dua lokasi kajian (Tabobo dan Kao) memiliki fluktuasi nilai yang bervariasi. Rerata suhu udara tertinggi di stasiun 1 (sungai Tabobo) adalah $32,33^{\circ} \mathrm{C}$ dan suhu terendah $32{ }^{\circ} \mathrm{C}$. Rerata suhu udara tertinggi di 
stasiun 2 (sungai Kao) adalah $28,67^{\circ} \mathrm{C}$ dan suhu terendah $28^{\circ} \mathrm{C}$. Rerata $\mathrm{pH}$ air tertinggi di stasiun 1 adalah 7,6 dan $\mathrm{pH}$ air terendah 6,7. Pada stasiun 2 Rerata $\mathrm{pH}$ air tertinggi adalah 6,8 dan rerata $\mathrm{pH}$ air terendah adalah 6,6. Kondisi $\mathrm{pH}$ air pada sungai Kao (kontrol) bersifat asam mendekati netral, sedangkan sungai Tabobo lebih bersifat basa $(\mathrm{pH}>7)$. Rerata DO tertinggi pada stasiun 1 (sungai Tabobo) adalah 4,17 dan rerata DO terendah adalah 3,8. Sedangkan rerata DO tertinggi pada stasiun 2 (sungai Kao) adalah 8,8 dan terendah adalah 8,6 .

Hasil analisis merkuri (Tabel 7) pada daun jenis Paspalum sp. dari Sungai Tabobo di hampir seluruh plot bagian kiri-kanan sungai memiliki kadar merkuri terukur dibawah standar yang ditetapkan $(<0,01 \mathrm{ppb})$, sedangkan kadar merkuri terukur yang tinggi terdapat pada daun tumbuhan jenis Paspalum sp. yang ada di plot 3 bagian hilir-kiri sungai(KI.3.3) yakni sebesar 11,57 ppb. Kadar merkuri terukur pada daun tumbuhan tingkat pohon jenis Macaranga sp. di plot 2 bagian tengah-kiri sungai (KI.2.2) menunjukkan nilai $36,45 \mathrm{ppb}$. Hasil analisis merkuri pada daun tumbuhan lantai jenis Panicum repens L. dan daun tumbuhan tingkat pohon jenis Macaranga semiglobosa J.J.S. dari Sungai Kao menunjukkan nilai dibawah ambang batas $(<0,01 \mathrm{ppb})$.

Berdasarkan hasil uji kadar merkuri pada organ vegetatif (daun) di dua lokasi dengan Analyzer mercury, diperoleh nilai tertinggi kadar merkuri terukur terdapat pada daun jenis Paspalum sp.di bagian kiri-hilir sungai (nomor plot KI.3.3) dengan nilai 11,45 ppb. Nilai ini telah melampaui nilai ambang batas yang ditentukan $(0,01 \mathrm{ppb})$ pada tumbuhan. Nilai merkuri terukur yang tinggi ini (walaupun hanya pada 1 plot), dapat mempengaruhi lingkungan perairan sungai secara keseluruhan. Kadar merkuri terukur pada sampel daun tumbuhan lantai jenis Panicum repens L. Dari sungai Kao (kontrol) masih dibawah ambang batas. Meskipun demikian, potensi keberadaan merkuri di perairan sungai Kao tetap ada karena keberadaan antara kedua sungai (Tabobo dan Kao) secara geografis masih berada pada satu daratan (Pulau Halmahera), sehingga kemungkinan ditemukannya merkuri pada sungai lain (selain sungai Tabobo) dapat terjadi melalui siklus hidrologi. Proses evaporasi molekul air dan merkuri dalam bentuk ion merkuri dari sungai Tabobo, dapat menggumpal membentuk awan, bergerak mengikuti angin dan turun dalam bentuk hujan pada daerah lain termasuk sungaisungai yang berdekatan.

Hasil pengukuran debit air di dua lokasi kajian, menunjukkan bahwa di sungai Tabobo memiliki debit air yang lebih tinggi dibandingkan dengan sungai Kao. Tinggi rendahnya nilai debit air pada sungai kajian disebabkan oleh beberapa faktor, yakni lebar sungai, kedalaman sungai, dan faktor musim (hujan/kemarau). Pada saat musim hujan, debit air akan meningkat cukup signifikan dibanding musim kemarau. Debit air yang tinggi dapat mempengaruhi tinggi rendah kadar merkuri pada perairan sungai

Berdasarkan data sekunder curah hujan dari Badan Meteorologi dan Geofisika (BMG) Kabupaten Halmahera Utara di Galela, dapat diperkirakan bahwa hubungan kemiripan vegetasi yang ada di dua lokasi kajian dapat berubah, tergantung faktor-faktor lingkungan, termasuk intensitas curah hujan. Curah hujan pada 3 tahun terakhir dikategorikan masih relatif rendah ( $\pm<1000 \mathrm{~mm} /$ tahun), sehingga hal ini dapat menyebabkan beberapa spesis dari Familia Poaceaee (rumput-rumputan) dapat mati karena kekeringan. Tetapi pada saat-saat tertentu, intensitas curah hujan yang optimal (1000-2500 $\mathrm{mm} /$ tahun $)$ dapat memberikan kesuburan pada jenis tumbuhan lantai yang ada di dua lokasi kajian, khususnya pada bulan Juni-Juli tahun 2013.

\section{KESIMPULAN}

1. Ditemukan 18 jenis tumbuhan lantai dan 3 jenis tumbuhan tingkat pohon di sekitar quarry pengelondongan emas dengan kerapatan tertinggi untuk tumbuhan lantai adalah jenis Paspalum sp. (52\%) dan nilai penting tertinggi untuk tingkat pohon adalah jenis Macaranga sp. (152,73\%). Di sungai Kao ditemukan sebanyak 3 jenis tumbuhan lantai dan 3 
jenis tumbuhan tingkat pohon. Kerapatan tertinggi untuk tumbuhan lantai adalah jenis Panicum repens L. (47\%), dan dan nilai penting tertinggi untuk tingkat pohon adalah jenis Macaranga semiglobosa J.J.S. (134,54\%). Sedangkan di sungai Umbul Nila Klaten, ditemukan 21 jenis tumbuhan lantai yang tergolong dalam 19 famili, dengan kerapatan tertinggi adalah jenis Commelina longifolia Lamk (22\%).

2. Hasil analisis kadar merkuri pada daun jenis Paspalum sp. di bagian kanan sungai (hulu, tengah dan hilir) serta di bagian kiri (hulu dan tengah) Sungai Tabobo, menunjukkan nilai merkuri dibawah standar yang ditetapkan $(<0,01$ ppb), sedangkan di bagian kiri-hilir sungai Tabobo (nomor plot KI.3.3) menunjukkan kadar merkuri terukur pada daun tumbuhan jenis Paspalum sp. sebesar $11.57 \mathrm{ppb}$. Kadar merkuri terukur pada daun tumbuhan tingkat pohon jenis Macaranga sp. menunjukkan nilai 36,45 ppb. Hasil analisis merkuri pada daun tumbuhan lantai jenis Panicum repens L. dan daun tumbuhan tingkat pohon jenis Macaranga semiglobosa J.J.S. dari Sungai Kao menunjukkan nilai dibawah ambang batas $(<0,01 \mathrm{ppb})$.

\section{DAFTAR PUSTAKA}

Edward. 2008. Pengamatan Kadar Merkuri di Perairan Teluk Kao (Halmahera) dan Perairan Anggai (Pulau Obi) Maluku Utara. Makara Sains. vol 12(2): 97-101.
Moro HKEP. 2011. Keanekaragaman Jenis Tumbuhan Penyusun Vegetasi Lantai Sekitar Quarry di Kawasan Tambang Emas Tradisional, Sekotong, Lombok Barat. [Tesis]. Yogyakarta: Fakultas Biologi. Universitas Gadjah Mada.

Palar H. 2008. Pencemaran dan Toksikologi Logam Berat. Cetakan keempat. Jakarta: Penerbit Rineka Cipta.

Rahayu S, Widodo RH, van Noordwijk M, Suryadi I, Verbist B. 2009. Monitoring Air di Daerah Aliran Sungai. Bogor: World Agroforestry Centre - Southeast Asia Regional Office. hal 104

Tarigan MS, Edward. 2003. Kondisi Hidrologi Perairan Teluk Kao, Pulau Halmahera, Maluku Utara. Jakarta: Pusat Penelitian Oseanografi Lembaga Ilmu Pengetahuan Indonesia.

Tandjung SD. 2007. Pencemaran Lingkungan. Yogyakarta: Fakultas Biologi dan Program Pascasarjana Universitas Gadjah Mada.

WHO. 1990. Methylmercury in Environmental Health Criteria 101. Geneva: World Health Organization.

Whittmann G. 1979. Toxic Metals. In: Metal pollution in the Aquatic Environment. Forstner and G.T.W. Whittmann (Ed). Berlin: Springer-Verlag. pp 3-70.

Zam zam Z. 2008. Profil Sebaran Merkuri di Daerah Penambangan Emas Kecamatan Malifut, Kabupaten Halmahera Barat Propinsi Maluku Utara. [Tesis]. Yogyakarta: Program Studi Ilmu Kimia Pascasarjana Universitas Gadjah Mada. 